\title{
Stem Cell Factories - the Rebirth of Tissue Engineering and Regenerative Medicine
}

\author{
Beat M. Frey Steffen M. Zeisberger Simon P. Hoerstrup \\ ${ }^{a}$ Blood Transfusion Service Zurich, Zurich-Schlieren, Switzerland; \\ ${ }^{b}$ Wyss Translational Center Zurich, Regenerative Medicine Technologies Platform, University of Zurich and ETH Zurich; Zurich, Switzerland; \\ c Institute for Regenerative Medicine (IREM), University of Zurich, Zurich, Switzerland
}

\begin{abstract}
Uncountable dreams, myths and excitements on artificial generation of tissues, organs, and even whole organisms accompany mankind's history to master health and disease. The creation of Eve out of Adam's rip, the generation of Prometheus without sexual reproduction in the Greek mythology, and the failing trial by Doctor Faustus in Goethe's poetry to build a living Homunculus illustrate the desire of mankind to overcome sickness and perishability [1]. With the emergence of empirical sciences during and after the Enlightenment era, the physicochemical understanding of man and his failures led to the discoveries of modern developmental biology [2], which were culminating in seismic achievements such as cloning of the sheep Dolly, growing of a human ear on a mouse - the so-called auriculosaurus - or the isolation of omnipo-
\end{abstract} tent human embryonic stem cells $[2,3]$. Although tissue engineering (TE) and regenerative medicine (RM) - often reflected by the acronym 'TERM' - are used synonymously and interchangeably in literature, the two areas of medical science pursue different focus and at the same time are complementary to each other [4]. TE goes back to early work by Vacanti, Langer, Green, Matapurkar and many others, combining in vitro isolated and expanded organ-specific cells in co-existence with artificial biodegradable matrix scaffolds to replace diseased, defect or missing organ tissue such as bone, cartilage, liver, ureter and others in attempt to generate in vivo engineered (induced) organ tissue [5-8]. Publications on TE started to appear as early as 1990 while the more comprehensive entity of RM appeared in the literature only by 2000 and thereafter [9]. There are many, ever changing definitions of RM in the literature reflecting evolving science and technologies involved but also taking care of society's needs driven by population growth and demographic changes. One of the most comprehensive outline of today's RM is given by Greenwood et al. [10] in 2006 which covers also the progresses made since then: 'Regenerative Medicine is an emerging interdisciplinary field of research and clinical application focused on the repair, replacement or regeneration of cells, tissue or organs to restore impaired function resulting from any cause, including congenital defects, disease, trauma and aging. It uses a combination of several technological approaches that moves it beyond traditional transplantation and replacement therapies. These approaches may include, but are not limited to, the use of soluble molecules, gene therapy, stem cell transplantation, tissue engineering and reprogramming of cell and tissue types'.

The interdisciplinarity of TERM goes far beyond medical sciences such as transplantation, immunology, and stem cell biology. It rather integrates disciplines such as system biology, nanotechnology, material science, genetics, and bioengineering in an effort to restore or replace organs and their function. However, spectacular successes in experimental settings, such as cloning of mammalians, the discovery of human embryonic stem cells and finally the reprogramming of terminally differentiated cells into various body cells via induced pluripotent stem cells [11-15], ignited hope and overreaching expectations of scientific and lay auditorium leading Time magazine to claim tissue engineer as being 'The Hottest Job' for the future [16]. By 2000, there were 66 companies in the USA working in the field and having a capital value of USD 2.5 billion [16]. In the meantime, failures in early applications and mature understanding of (patho)biology of diseased or deteriorated tissue have fostered new and holistic concepts of TERM: Regenerative technologies and services strive to boost innate repair processes and provide scalable production and standardized application of clinical grade biotherapeutics. Critical areas include regulatory pathways for RM therapies, strategic partnerships, coordination of resources, developing of standards, priorities for industry, biobanking, and integration of new technologies [17, 18]. According to the US Department of Health and Human Services, RM offers the potential to cure countless fatal and debilitating conditions through therapies that spur in vivo regeneration and in vitro creation of healthy tissue for implantation [19]. In the prospect, 7 of 10 deaths in the world will be caused by non-communicable diseases,

\section{KARGER}

Fax +497614520714
(๑) 2016 S. Karger GmbH, Freiburg

$1660-3796 / 16 / 0434-0244 \$ 39.50 / 0$
Dr. Beat M. Frey

Blood Transfusion Service Zurich

Rütistrasse 19

8952 Zurich-Schlieren, Switzerland

bm.frey@zhbsd.ch 
and by 2030 the most prevalent chronic conditions responsible for morbidity and mortality will be cardiovascular diseases, cancer, diabetes, and respiratory diseases [20]. Medical progress, robust success in combating life-threatening acute conditions, and demographic changes are the main reasons for these megatrends. Traditional health care approaches will be overburdened either by limited resources, restricted applicability or treatment related side effects [20]. Strategies for therapeutic repair as offered by TERM now rely on the 'R3' paradigm [21]: Replacement of tissue by transplantation, regeneration of tissue by stem cell engraftment, and rejuvenation of resident cells by cell activation with the ultimate goal of 'restitutio ad integrum'.

In the upcoming two special issues of Transfusion Medicine AND HeMOTHERAPY we provide overviews on TERM activities of various medical specialties. The first three manuscripts describe properties and application of stem cells isolated from anatomically not defined organs such as hematopoietic and mesenchymal cells as well as adipose tissue [22-24]. Besides immune modulatory effects executed by these cells, they might transdifferentiate into functional cells replacing and/or regenerating organ-specific tissue.
The following manuscripts describe organ-residing stem cells which can be (re-)activated and used for repair of structural and functional deficiencies of the heart [25-27], bone [28], brain [29], bladder [30], and teeth [31] as examples. Also logistic, regulatory and safety issues for extensively in vitro manipulated cells will be addressed in the last two manuscripts by Hartmann-Fritsch et al. [32] and Simeon-Dubach et al. [33].

The purpose of TERM is to bridge advances in stem cell biology with individualized disease management [21] by integration of new physicobiological approaches such as mechanobiology and chip technology [34, 35]. However, convincing clinical studies on TERM products and procedures providing adequate power and credibility are urgently needed [36] to reinforce TERM on the marketplace of health care and life science industry. Learning from the past [37], strategic exchange of experts [38], financing and returns of innovations [39, 40], and regulatory issues [41] will be the ingredients to make TERM driving. After decades of hopes and hypes, TERM is about to embark into a new era to deliver mature, integrative, and holistic health care services designed for cure of disease considering individual regenerative capacity [42].

\section{References}

1 Meyer U: The history of tissue engineering and regenerative medicine in perspective; in Meyer UM, Handschel T, Wiesmann HP (eds): Fundamentals of Tissue Engineering and Regenerative Medicine, Heidelberg, Springer, 2009, p 5-12.

2 Kaul, H. Ventikos Y: On the genealogy of tissue engineering and regenerative medicine. Tissue Eng Part B Rev 2014;21:203-217.

3 Slingerland AS, Smits AI, Bouten CV: Then and now: hypes and hopes of regenerative medicine. Trends Biotechnol 2013;31:121-123.

4 KatariR., Peloso A; Orlando G: Tissue engineering and regenerative medicine: semantic considerations for an evolving paradigm. Front Bioeng Biotechnol 2015;2: 57.

5 Langer R. VacantiJP: Tissue engineering. Science 1993; 260:920-92.

6 Green W.T Jr:Articular cartilage repair. Behavior of rabbit chondrocytes during tissue culture and subsequent allografting. Clin Orthop Relat Res, 1977;124: 237-250.

7 Matapurkar BG: Large recurrent incisional hernia: ultrasonographic mapping of abdominal wall defects and repair by Marlex peritoneal sandwich techniques. Indian J Surg 1995:321-325.

$\checkmark$ Vacanti JP, Morse MA, Saltzman WM, Domb AJ, Perez-Atayde A, Langer R: Selective cell transplantation using bioabsorbable artificial polymers as matrices. J Pediatr Surg 1988;23:3-9.

9 Fisher MB, Mauck RL: Tissue engineering and regenerative medicine: recent innovations and the transition to translation. Tissue Eng Part B Rev 2013;19:1-13.

10 Greenwood HL, Singer PA, Downey GP, Martin DK, Thorsteinsdóttir H, Daar AS: Regenerative medicine and the developing world. PLoS Med 2006;3e381.

11 Wadman M: Cloning special: Dolly: a decade on. Nature 2007;445:800-801.

12 Thomson JA, Itskovitz-Eldor J, Shapiro SS, Waknitz MA, Swiergiel JJ, Marshall VS, Jones JM: Embryonic stem cell lines derived from human blastocysts. Science 1998;282:1145-1147.
3 Shamblott MJ, Axelman J, Wang S, Bugg EM, Littlefield JW, Donovan PJ, Blumenthal PD, Huggins GR, Gearhart JD: Derivation of pluripotent stem cells from cultured human primordial germ cells. Proc Natl Acad Sci U S A 1998;95:13726-13731.

14 Amit M, Carpenter MK, Inokuma MS, Chiu CP, Harris CP, Waknitz MA, Itskovitz-Eldor J, Thomson JA: Clonally derived human embryonic stem cell lines maintain pluripotency and proliferative potential for prolonged periods of culture. Dev Biol 2000;227:271278.

15 Cao N, Huang Y, Zheng J, Spencer CI Zhang Y1, Fu JD, Nie B, Xie M, Zhang M1, Wang H, Ma T, Xu T, Shi G, Srivastava D, Ding S: Conversion of human fibroblasts into functional cardiomyocytes by small molecules. Science 2016;352:1216-1220.

16 Kemp P: History of regenerative medicine: looking backwards to move forwards. Regen Med 2006;1:653669.

17 Hunsberger J, Harrysson O, Shirwaiker R Starly B, Wysk R, Cohen P, Allickson J, Yoo J, Atala A: Manufacturing road map for tissue engineering and regenerative medicine technologies. Stem Cells Transl Med 2015;4:130-135.

18 Terzic A, Pfenning MA Gores GJ2, Harper CM Jr: Regenerative medicine build-out. Stem Cells Transl Med 2015;4:1373-1379.

19 US Department of Health and Human Services, W., DC, 2020:A New Vision - a Future for Regenerative Medicine. 2005. http://medicine.osu.edu/regenerativemedicine/documents/2020vision.pdf (last accessed July 18, 2016).

20 Terzic A, Nelson TJRegenerative medicine primer. Mayo Clin Proc, 2013;88:766-775.

21 Nelson TJ, Behfar A, Terzic A: Strategies for therapeutic repair: the ' $R(3)$ ' regenerative medicine paradigm. Clin Transl Sci 2008;1:168-171.

22 Müller A, Huppertz S, Henschler R: Hematopoietic stem cells in regenerative medicine: astray or on the path? Transfus Med Hemother 2016:43: DOI: $10.1159 / 000447748$.
3 Schäfer R, Spohn G, Baer PC: Mesenchymal stem/stromal cells in regenerative medicine: can preconditioning strategies improve therapeutic efficacy? Transfus Med Hemother 2016:43: DOI: 10.1159/000447458.

24 Frese L, Dijkman P, Hoerstrup S,: Adipose tissue-derived stem cells in regenerative medicine. Transfus Med Hemother 2016:43: DOI: 10.1159/000448180.

25 Emmert M, Cambria E, Steiger J, Günter J, Hoerstrup S: Cardiac stem cell therapy: the next generation. Transfus Med Hemother 2016:43: DOI: 10.1159/ 000448179 .

26 Dijkman P, Fioretta E, Frese L, Hoerstrup S: Heart valve replacements with regenerative capacity. Transfus Med Hemother 2016:43: DOI: 10.1159/000448181.

27 Mallone A, Weber B, Hoerstrup S: Regenerative medicine - update on cardiovascular regenerative technologies. Transfus Med Hemother 2016:43: DOI: $10.1159 / 000447749$.

28 Bhattacharya I, Ghayor C, Weber, FE: The Use of adipose tissue derived progenitors in bone tissue engineering - a review. Transfus Med Hemother 2016:43: DOI: $10.1159 / 000447494$.

29 Jessberger S: Stem cell-mediated regeneration of the adult brain. Transfus Med Hemother 2016:43: DOI: 10.1159/000447646.

30 Smolar J, Salemi S, Horst M, Sulser T, Eberli D: Stem cells in functional bladder engineering. DOI: 10.1159/ 000447977.

31 Ruangsawasdi N, Zehnder M, Patcas R, Ghayor C, Weber FE: Regenerative dentistry: animal model for regenerative endodontology. Transfus Med Hemother 2016:43: DOI: 10.1159/000447664.

32 Hartmann-Fritsch F, Marino D, Reichmann E: About ATMPs, SOPs and GMP: the hurdles to produce novel skin grafts for clinical use. Transfus Med Hemother 2016:43: DOI: 10.1159/000447645.

33 Simeon-Dubach D, Zeisberger SM, Hoerstrup SP: Quality assurance in biobanking for pre-clinical research. Transfus Med Hemother 2016:43: DOI: $10.1159 / 000448254$. 
34 Guilak F, Butler DL, Goldstein SA, Baaijens FP: Biomechanics and mechanobiology in functional tissue engineering. J Biomech 2014;47:1933-1940.

35 Huh D, Matthews BD, Mammoto A, Montoya-Zavala $\mathrm{M}, \mathrm{Hsin} \mathrm{HY}$, Ingber DE: Reconstituting organ-level lung functions on a chip. Science 2010;328:1662-1668.

36 Sloff M, de Vries R, Geutjes P, IntHout J, RitskesHoitinga M, Oosterwijk E, Feitz W: Tissue engineering in animal models for urinary diversion: a systematic review. PLoS One 2014;9:e98734.
Berthiaume F, Maguire TJ Yarmush ML: Tissue engineering and regenerative medicine: history, progress, and challenges. Annu Rev Chem Biomol Eng 2011;2: 403-30.

Johnson PC, Mikos AG, Fisher JP, Jansen JA: Strategic directions in tissue engineering. Tissue Eng 2007;13: 2827-2837.

39 French A, Buckler RL, Brindley DA: Commercialization of regenerative medicine: learning from spin-outs. Rejuvenation Res 2013;16:164-170.
40 Mason C, Manzotti E: Regenerative medicine cell therapies: numbers of units manufactured and patients treated between 1988 and 2010. Regen Med 2010;5: 307-313.

41 Blasimme A, Rial-Sebbag E: Regulation of cell-based therapies in Europe: current challenges and emerging issues. Stem Cells Dev 2013;22(suppl 1):14-19.

42 Terzic A, Behfar A: Stem cell therapy for heart failure: ensuring regenerative proficiency. Trends Cardiovasc Med 2016;26:395-404. 